\title{
EVALUATION OF RESISTANT GENOTYPE AGAINST BRINJAL SHOOT AND FRUIT BORER (Leucinodesorbonalis Guenee)
}

\author{
M.A. Mannan, S. Ferdousi, M.M. Kamal and S. Das \\ Agro- technology Discipline, Khulna University, Khulna-9208, Bangladesh \\ Corresponding E-mail: mannanku@gmail.com
}

(Received: 31July 2021, Accepted: 12 September 2021)

Keywords: BSFB, infestation, brinjal, genotypes, resistant, varieties

\begin{abstract}
Brinjal shoot and fruit borer (BSFB), Leucinodesorbonalis Guenee, is a devastating pest of brinjal (Solanummelongena L.) in all brinjal growing countries across the globe. Ten genotypes of brinjal were evaluated against the pest in experimental field of Khulna University, Bangladesh following arandomized block design with three replications. The genotypes were BARI Hybrid Begun-2, BARI Hybrid Begun-4, BARI BT-4, Begun-4, BARI Begun-9 and BARI Begun-10, Local Cultivar-1, Local Cultivar-2, Local Cultivar3, Local Cultivar-4 and BARI Begun-4among the ten brinjal genotypes, reduced shoot and fruit infestation were recorded in local cultivar-1 and BARI Begun 2. On degree of infestation, BARI hybrid BT begun 4 appeared to be resistant while rest of the genotypes were susceptible or highly susceptible. Volume index was documented to be high in BARI hybrid Begun 4 and low in local cultivar 3, while shape index was high in cultivar 2 and low in BARI hybrid begun 4 and BARI Begun-10. BARI Hybrid Begun 4 possessed greater meso and pericarp thickness although those were not resistant. Above all, using resistant genotypes of BARI hybrid BT begun 4 may be considered as a last resort inan optimized IPM package to ensure maximum brinjal productivity.
\end{abstract}

\section{Introduction}

In Bangladesh, brinjal is one of the most popular and favoured vegetables which is grown throughout the country.It is commercially cultivated in Jessore, Rajshahi, Narsinghdi, Dhaka, Comilla, and Bogra districts. It is grown in both Rabi and Kharif season in Bangladesh. Rabi brinjal has been cultivated over 82000 acres of land and the total production was 360000 Tons and Kharif brinjal has been cultivated over 47000 acres of land and the total production was 170000 tons (BBS, 2020). Regarding nutritional value, brinjal possesses a very low caloric value but high content of vitamins, minerals, and bioactive compounds for human health (Raigón et al., 2008; Plazas et al., 2014b; Docimo et al., 2016).

Brinjal is quite susceptible to several environmental stresses, especially acute temperature, drought, salinity, and inadequate moisture stresses (Kalloo, 1993) which affect the growth and development of the plant. It has a relatively longer growth period and life span, brinjal is more vulnerable than other vegetable crops to a broad range of plant diseases, pests, nematodes, and weeds. The major handicap to the sustainable productivity of brinjal in Bangladesh is the high incidence of insect pests.

In total 9 species of insects belonging to 7 families of 4 orders have been reported as a pest in brinjal field e.g. Epilachna beetle (Epilachnadodecastigma), Jassid (Amrascabiguttula), Whitefly (Bemisiatabaci), Shoot and fruit borer (Leucinodesorbonalis), Rice bug (Leptocorisaacuta), Aphid (Aphis gossypii), Thrips (Thripshawaiiensis) and Leaf hopper (Amrascadevastans) (Amin et al., 2018). Among them, Brinjal Shoot and Fruit Borer (BSFB) is reported to induce about 16 and $70 \%$ damage to shoots and fruits, respectively (Kar et al., 2020). It is recognized as the most damaging pest of brinjal 
(Taylo et al., 2016). It scales down the productivity as well as the quality of marketable fruits of brinjal. The larval stage of the pest is mainly catastrophic and can cause severe damage to fruits and shoots. Newly hatched larvae invade the vascular bundle of the plant and hit translocation of food and nutrients towards shoots. Approximately 4-6 healthy fruits can be destroyed because of the attack of a single Larvae (Jayaraj and Manisegaran, 2010). Because of the concealed mode of life, it is the most serious pest of brinjal (Sardana et al., 2004). This insect pest is accountable for $70-92 \%$ of yield loss (Chakraborti and Sarkar, 2011).

There are several measures to mitigate this including spraying of chemical insecticides, application of botanical pesticides, adopting IPM technologies, using resistant varieties and so on.. A survey report revealed that $98 \%$ of Bangladeshi farmers are dependent entirely on spraying insecticides to control BFSB (Karim, 2004). So, it is a burning question to identify and use of most effective resistant varieties, proper chemical insecticide and effective botanical pesticides to ensure eco-friendly pest management under IPM technology.

\section{Materials and Methods}

The present study was carried out at the experimental field of the Germplasm Centre of Khulna University, Bangladesh during September 2020 to May, 2021. The study area is situated at $24.09^{\circ}$ North latitude and $90.26^{\circ}$ East Longitudes with an elevation of 8.4 meter from the sea level.The climatic condition of Khulna University has unimodal rainfall pattern; most of the rainfalloccurs during the months of May to September. The average rainfall is usually higherthan $200 \mathrm{~mm}$ during November to March. The warmer months are April, May and June with mean maximum temperature of $31-34^{\circ} \mathrm{c}$ and the cold months are November, December and January when the temperature ranges from 10$19^{\circ} \mathrm{C}$.

The area belongs to the Ganges flood plain (AEZ-13), clay loam in texture having low organic matter $(1.12 \%)$ moderately slow permeability and deficient in nitrogen, potassium and Sulphur. The soil is mostly alkaline and somewhat saline in nature having $\mathrm{pH} 6.5$ to 8.5 .

Brinjal seeds of 10 varieties viz. BARI Hybrid Begun-2, BARI Hybrid Begun-4, BARI BT-4, Begun-4, BARI Begun-9 and BARI Begun-10, Local Cultivar-1, Local Cultivar-2, Local Cultivar-3, and Local Cultivar-4 and BARI Begun-4 which were collected from Horticulture Division, Bangladesh Agricultural Research Institute (BARI), Joydebpur, Gazipur, the local ones from the farmers of the Khulna region. A small seedbed measuring $5 \mathrm{~m} \times 1 \mathrm{~m}$ was prepared and seeds were sown there. Standard seedling raising practice was followed.

The plots were lightly irrigated regularly for ensuring proper development of the seedlings. The seedbed was mulched for ensuring seed germination, proper growth and development of the seedlings. Thirty-six day-old (3/4 leaf stage) healthy seedlings were transplanted in $50 \mathrm{~cm}$ apart in 2.0 meter $\times 2.5$ size plots in rows in three replications laid out inRCBD design with 3 replications. Each row separated by $50 \mathrm{~cm}$ which contained 16 plants of each variety. After transplanting light irrigation was given to each pit. Dead or damaged seedlings were replaced immediately by new ones from the stock. Supple mentary irrigation was applied at an interval of 2-3 days. Propping of each plant using bamboo sticks (1 $\mathrm{m}$ height) was done for providing extra support to avoid lodging of theplants. Weeding andmulching were given whenever necessary. Cow dung @ 15 tons, 250, 150 and $125 \mathrm{~kg}$ of Urea, TSP and MoP, respectively per hectare. The half of cow dung and TSP were applied as basal dose during land preparation. The remaining cow dung, TSP and, one- third of MoP were applied in the pits at transplantation of brinjal seedlings. The entire dose of urea and the rest of MoPwere applied as top dressing. The first top dressing of urea (one third) was made at 15 days after transplanting. One third of urea and one- third of MoP at the time of flower initiation and rest of urea and MoP at the time of fruit development.

The incidence of Leucinodesorbonalis Guenee was recorded at seven days intervals starting from the 
first appearance of shoot and fruit borer after transplanting the brinjal crop and continued till the harvesting of the crop. The infestation and intensity of Leucinodesorbonalis Guenee on young plants were recorded by counting infected and healthy shoots on randomly counted at each picking (weekly). Damaged (\%) on shoot and fruit was calculated by recording the number of total and infestedshoot and fruit.

The observation was converted into percentage and germplasm were classified according to the scoring pattern adopted. The germplasm was categorized as Highly Resistance (\%), Resistant (0-15\%), Moderately Resistant (16-30\%), Susceptible (31-45\%) and Highly Susceptible (above 46\%) respectively. The fruit characters studies include length, diameter, shape and volume index, length of peripheral seed-ring and seedless area, thickness of mesocarp and pericarp.

Numbers of fruits per plant were recorded from 5 randomly selected plants from each plot.Random samples of fruits of 5 plants (10 fruits from each plant) were taken from each plot...

\section{For calculating various parameters, following formula were used}

Shape Index = Length fruit/fruit diameter,

Volume Index $=$ Length fruit $\mathrm{x}$ fruit diameter,

RLPS $=$ Length of peripheral seed ring/Total length of fruit,

RLSA $=$ Length of seed less area/Total length of fruit,

Where, RLPS $=$ Ratio of Length of Peripheral Seed Ring and RLSA = Ratio of Length of Seedless Area.

Total number of infested shoots and fruitsdue to the infestationby the natural population of BSFB from randomly selected 5 plants/replication were counted and recorded at every 10 days interval from 30 days after transplanting (DAT). Infestation percentage of BSFB on shoots and fruits were calculated.Relative resistance of theplants against BSFB was estimated on the basis of shoot and fruit damage severity. Those pest damage grading were done on this basis the grading index followed by Subbratnam and Butani(1981) (Table 1).

Tables 1. Pest damage grading due to BSFB attack on shoots and fruits of brinjal (Subbratnam and Butani, 1981).

\begin{tabular}{lcc}
\hline Grading & Percent shoot infestation & Percent fruit infestation \\
\hline Highly resistant (HR) & $<1.0 \%$ & $<5.0 \%$ \\
Resistant (R) & $1.1-2.0 \%$ & $5.1-15.0 \%$ \\
Moderately resistant (MR) & $2.1-3.0 \%$ & $15.1-25.0 \%$ \\
Susceptible (S) & $3.1-5.0 \%$ & $25.1-40.0 \%$ \\
Highly susceptible (FIS) & $>5.0 \%$ & $>40.0 \%$ \\
\hline
\end{tabular}

$\mathrm{BSFB}=$ Brinjal shoot and fruit borer

The critical difference was calculated for the comparison of different germplasm of brinjal. Simple correlation (r)between shoot and fruit borer Leucinonedsorbonalis Guen. and fruit infestation of different germplasm of brinjal and Fruit Characters. The quantitative data for the character were statically analyzed for Analysis of variance and the means were compared by DMRT as well as the correlation between these characters and the degree of fruitinfestation (Gomez and Gomez, 1984).

\section{Results and Discussion}

Brinjal cultivar-2 gave the tallest $(85.83 \mathrm{~cm}$ ) and it was the shortest in BARI begun-4 (plant height $45.83 \mathrm{~cm}$ ) in length among the tested cultivars (Table 2). Plants of other varieties were attended medium height. The highest number of leaves were also obtained from Local Cultivar-4. 
Length and breadth of the leaves of BARI Hybrid Begun-2 and BARI Hybrid Begun-4 were the highest than the other ones.Average number of shoots and infested shoot were observed in BARI Begun-10 (39.33 and 16.67 plant $^{-1}$, respectively).

Table 2. Growth Parameter of the varieties and shoot infestation

\begin{tabular}{lcccccc}
\hline Variety & $\begin{array}{c}\text { Plant } \\
\text { Height } \\
(\mathbf{c m})\end{array}$ & $\begin{array}{c}\text { Average No. } \\
\text { of Leaves } \\
\text { Plant }^{-1}\end{array}$ & $\begin{array}{c}\text { Average } \\
\text { length of } \\
\text { Leaf }(\mathbf{c m})\end{array}$ & $\begin{array}{c}\text { Average } \\
\text { Breadth of }_{\text {Leaf }(\mathbf{c m})}\end{array}$ & $\begin{array}{c}\text { No of } \\
\text { Shoots } \\
\text { Plant }^{-1}\end{array}$ & $\begin{array}{c}\text { No. of Infested } \\
\text { Shoots Plant }^{\mathbf{1}}\end{array}$ \\
\hline BARI Hybrid Begun-2 & $62.50 \mathrm{~b}$ & $53.33 \mathrm{bc}$ & $33.00 \mathrm{a}$ & $18.33 \mathrm{ab}$ & 30.67 & $13.67 \mathrm{abc}$ \\
BARI Hybrid Begun-4 & $55.33 \mathrm{bc}$ & $50.33 \mathrm{bcd}$ & $31.00 \mathrm{ab}$ & $19.83 \mathrm{a}$ & 28.33 & $11.00 \mathrm{bc}$ \\
BARI BTBegun-4 & $57.00 \mathrm{bc}$ & $45.33 \mathrm{bcd}$ & $28.67 \mathrm{bc}$ & $13.00 \mathrm{bcd}$ & 36.00 & $14.00 \mathrm{abc}$ \\
BARI Begun-9 & $53.17 \mathrm{bc}$ & $44.00 \mathrm{~cd}$ & $26.33 \mathrm{~cd}$ & $14.67 \mathrm{abcd}$ & 29.00 & $9.00 \mathrm{c}$ \\
BARI Begun-10 & $55.23 \mathrm{bc}$ & $39.89 \mathrm{~d}$ & $30.67 \mathrm{ab}$ & $19.33 \mathrm{a}$ & 39.33 & $16.67 \mathrm{a}$ \\
Local Cultivar-1 & $51.17 \mathrm{bc}$ & $57.17 \mathrm{bcd}$ & $28.50 \mathrm{bc}$ & $17.00 \mathrm{abc}$ & 34.67 & $12.00 \mathrm{abc}$ \\
Local Cultivar-2 & $59.17 \mathrm{bc}$ & $52.67 \mathrm{bcd}$ & $30.17 \mathrm{abc}$ & $13.17 \mathrm{bcd}$ & 31.67 & $16.33 \mathrm{ab}$ \\
Local Cultivar-3 & $49.67 \mathrm{bc}$ & $58.00 \mathrm{~b}$ & $22.00 \mathrm{e}$ & $12.00 \mathrm{~cd}$ & 31.67 & $12.00 \mathrm{abc}$ \\
Local Cultivar-4 & $85.83 \mathrm{a}$ & $73.67 \mathrm{a}$ & $24.33 \mathrm{de}$ & $11.00 \mathrm{~d}$ & 26.00 & $11.33 \mathrm{abc}$ \\
BARI Begun-4 & $45.83 \mathrm{c}$ & $46.50 \mathrm{bcd}$ & $27.58 \mathrm{bcd}$ & $13.17 \mathrm{bcd}$ & 30.67 & $16.00 \mathrm{ab}$ \\
\hline LSD $(0.05)$ & 13.68 & 13.26 & 4.10 & 5.87 & - & 5.38 \\
\hline
\end{tabular}

Data in a column with same letter do not differ significant by LSD Test

Fruit characteristics are consideredas the important ones forresistant breeding and fruit yield. There were significant differences among the brinjal varieties in respect of yield contributing character and yield (Table 3 ). The highest number of flowers and fruits were found in Local Cultivar-4 (106 and 32, respectively) and those were the lowest in BARI Begun-4 (44.33 and 9.00, respectively). The highest infested fruits and larvae were obtained from BARI Hybrid Begun-2 and BARI Hybrid Begun-4 (21.67 and 13.33, respectively). Average fruit weight per plant was the highest $(9.53 \mathrm{~kg})$ and weight of individual fruit in BARI BT Begun-4 $(273.63 \mathrm{~g})$. Average yield was recorded from Local Cultivar-3 (165.00 t/ha) followed by BARI BT Begun-4 (99.23 t/ha).

Table 3. Yield contributing parameters and fruit yield of the varieties and number of larvae

\begin{tabular}{lccccccc}
\hline Variety & $\begin{array}{c}\text { No. of } \\
\text { Flowers } \\
\text { Plant }^{-1}\end{array}$ & $\begin{array}{c}\text { Total No. } \\
\text { of Fruits }^{\text {Plant }}{ }^{-1}\end{array}$ & $\begin{array}{c}\text { No. of } \\
\text { Infested } \\
\text { Fruit }_{\text {Plant }^{-1}}\end{array}$ & $\begin{array}{c}\text { No. of } \\
\text { Larvae } \\
\text { Plant }^{-1}\end{array}$ & $\begin{array}{c}\text { Average } \\
\text { Fruit } \\
\text { Weight } \\
\text { Plant }^{-1}(\mathbf{K g})\end{array}$ & $\begin{array}{c}\text { Weight of } \\
\text { Individual } \\
\text { Fruit }(\mathbf{g})\end{array}$ & $\begin{array}{c}\text { Fruit } \\
\text { Yield } \\
(\mathbf{t} / \mathbf{h a})\end{array}$ \\
\hline BARI Hybrid Begun-2 & $56.67 \mathrm{~b}$ & $27.00 \mathrm{ab}$ & $21.67 \mathrm{a}$ & $9.67 \mathrm{ab}$ & $7.23 \mathrm{bcd}$ & $133.67 \mathrm{~d}$ & $115.42 \mathrm{~b}$ \\
BARI Hybrid Begun-4 & $73.67 \mathrm{ab}$ & $23.67 \mathrm{abc}$ & $17.67 \mathrm{ab}$ & $13.33 \mathrm{a}$ & $7.97 \mathrm{ab}$ & $94.47 \mathrm{e}$ & $71.45 \mathrm{~cd}$ \\
BARI BTBegun-4 & $6300 \mathrm{ab}$ & $21.33 \mathrm{bcd}$ & $1.00 \mathrm{e}$ & $2.00 \mathrm{e}$ & $6.27 \mathrm{bcd}$ & $273.63 \mathrm{a}$ & $99.23 \mathrm{bc}$ \\
BARI Begun-9 & $67.00 \mathrm{ab}$ & $14.33 \mathrm{de}$ & $5.33 \mathrm{de}$ & $3.67 \mathrm{de}$ & $5.23 \mathrm{~d}$ & $74.50 \mathrm{f}$ & $33.84 \mathrm{~d}$ \\
BARI Begun-10 & $71.67 \mathrm{ab}$ & $15.33 \mathrm{cde}$ & $8.00 \mathrm{cde}$ & $5.00 \mathrm{cde}$ & $5.53 \mathrm{~d}$ & $79.23 \mathrm{f}$ & $38.69 \mathrm{~d}$ \\
Local Cultivar-1 & $75.33 \mathrm{ab}$ & $20.67 \mathrm{bcd}$ & $1467 \mathrm{abc}$ & $4.00 \mathrm{de}$ & $7.56 \mathrm{abc}$ & $136.40 \mathrm{~d}$ & $90.23 \mathrm{bc}$ \\
Local Cultivar-2 & $80.67 \mathrm{ab}$ & $17.00 \mathrm{cde}$ & $13.00 \mathrm{bcd}$ & $6.00 \mathrm{bcde}$ & $6.93 \mathrm{bcd}$ & $131.47 \mathrm{~d}$ & $71.55 \mathrm{~cd}$ \\
\hline
\end{tabular}




\begin{tabular}{lccccccc}
\hline Local Cultivar-3 & $86.00 \mathrm{ab}$ & $27.33 \mathrm{ab}$ & $20.67 \mathrm{ab}$ & $7.67 \mathrm{bcd}$ & $9.53 \mathrm{a}$ & $188.27 \mathrm{c}$ & $165.00 \mathrm{a}$ \\
Local Cultivar-4 & $106.00 \mathrm{a}$ & $32.00 \mathrm{a}$ & $18.33 \mathrm{ab}$ & $9.00 \mathrm{bc}$ & $7.73 \mathrm{ab}$ & $64.50 \mathrm{~g}$ & $66.24 \mathrm{~cd}$ \\
BARI Begun-4 & $44.33 \mathrm{~b}$ & $9.00 \mathrm{e}$ & $4.00 \mathrm{e}$ & $2.33 \mathrm{e}$ & $5.60 \mathrm{~cd}$ & $206.34 \mathrm{~b}$ & $59.68 \mathrm{~cd}$ \\
\hline LSD $(0.05)$ & 44.37 & 9.16 & 7.99 & 4.28 & 2.03 & 6.23 & 41.22 \\
\hline
\end{tabular}

Data in a column with same letter do not differ significantly by LSD Test

There were significant variations among the varieties in respect of shoot infestation (Table 4). Infestation percent of shoot by BSFB was recorded in brinjal germplasm, ranged from 32.33 to $52.33 \%$. The maximum shoot infestation (52.33\%) was found in BARI Begun-4, which was statistically similar to Local Cultivar-2 (51.40\%) followed by Local Cultivar-4 (43.67\%). The lowest shoot infestation was recorded from Local Cultivar-1 (32.33\%).

Infestation percent of fruit borer was recorded in brinjal germplasm, ranged from 4.20 to 80.60. Minimum mean infestation in fruits was found in BARI BTBegun-4 (4.20\%) while maximum in BARI Hybrid Begun-2 (80.60). Mean percent infestation of shoot and fruit borer in fruits has been presented in Table 4.

Comparable range of fruit infestation was 20.23 to $45.61 \%$ reported by Jat (2003), though they used different set of varieties/cultivars in their experiment. Kumar and Shukla (2002) was found 33 to 53\% damage of fruits in 12 different cultivars of brinjal. Similarly, Ashoke and Abhishek (2002) while evaluating 12 brinjal cultivars infield conditions reported 33.65-53.02\% fruit infestation of $L$. orbonalis larvae. Conversely, Chaudhary and Sharma (2000) found very low attack of brinjal shoot and fruit borer (2.88-5.64\%) during screening of nine genotypes of brinjal.

General equilibrium position of shoot infestation of different entries of brinjal was calculated on the basis of their infestation, which is varied between 9.0 to $52.33 \%$ shoot infestations (Table 4and 5). Only one genotype of brinjalviz, RARI BT Begun-4 had 9.00\% shoot infestation showing tolerance. Four entries like, BARI Hybrid Begun-4, BARI Begun-9, Local Cultivar-1 and Local Cultivar-4 weresusceptibleagainst this pest and other 5 varieties namely BARI Hybrid Begun-2, BARI Hybrid Begun-4 BARI Begun-10, Local Cultivar-2 and Local Cultivar-3 were categorized as highly susceptible genotype, respectively (Table 5). None of the varieties were found moderately tolerant and resistance againstfruit borer. Another categorization of tested entries against shoot and fruit borer done on the basis of rank allotted to the shoot as well as fruit infestation.

Table 4. Categorization of different germplasm of brinjal by ranking method based on shoot \& fruit infestation

\begin{tabular}{clcccc}
\hline $\begin{array}{c}\text { Sl. } \\
\text { No. }\end{array}$ & \multicolumn{1}{c}{ Germplasm } & $\begin{array}{c}\text { Shoot } \\
\text { Infestation }(\boldsymbol{\%})\end{array}$ & Rank & $\begin{array}{c}\text { Fruit infestation } \\
(\boldsymbol{\%})\end{array}$ & Rank \\
\hline 1 & BARI Hybrid Begun-2 & $43.27 \mathrm{bc}$ & HS & $80.60 \mathrm{a}$ & HS \\
2 & BARI Hybrid Begun-4 & $39.13 \mathrm{~cd}$ & $\mathrm{~S}$ & $75.60 \mathrm{a}$ & HS \\
3 & BARI BTBegun-4 & $9.00 \mathrm{cde}$ & $\mathrm{T}$ & $4.2 \mathrm{c}$ & $\mathrm{T}$ \\
4 & BARI Begun-9 & $34.50 \mathrm{ef}$ & $\mathrm{S}$ & $34.20 \mathrm{bc}$ & $\mathrm{S}$ \\
5 & BARI Begun-10 & $42.50 \mathrm{bc}$ & HS & $53.90 \mathrm{abc}$ & HS \\
6 & Local Cultivar-1 & $32.33 \mathrm{f}$ & $\mathrm{S}$ & $71.93 \mathrm{ab}$ & HS \\
7 & Local Cultivar-2 & $51.40 \mathrm{a}$ & HS & $55.23 \mathrm{abc}$ & HS \\
8 & Local Cultivar-3 & $36.67 \mathrm{def}$ & $\mathrm{S}$ & $72.77 \mathrm{ab}$ & HS \\
9 & Local Cultivar-4 & $43.67 \mathrm{~b}$ & HS & $57.50 \mathrm{abc}$ & HS \\
10 & BARI Begun-4 & $52.33 \mathrm{a}$ & HS & $45.47 \mathrm{abc}$ & HS \\
\hline
\end{tabular}

Table 5. Categories of the brinjal varieties of the present study based on average rank of shoot and fruit infestation

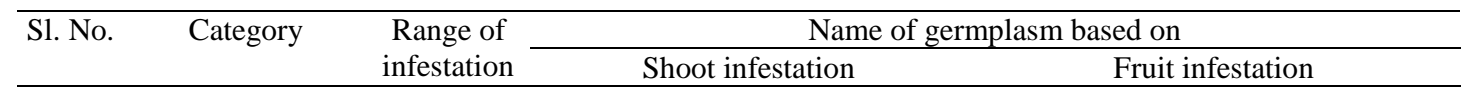




\begin{tabular}{|c|c|c|c|c|}
\hline 1 & $\begin{array}{l}\text { Highly } \\
\text { Resistance (HR) }\end{array}$ & $<5 \%$ & 0 & \\
\hline 2 & Resistance & $5.1-15$ & BARI BT Begun -4 & BARI BT Begun -4 \\
\hline 3 & $\begin{array}{l}\text { Moderately } \\
\text { Resistance (MR) }\end{array}$ & $15.1-25 \%$ & 0 & 0 \\
\hline 4 & Susceptible(S) & $\begin{array}{c}25.1- \\
40.0 \%\end{array}$ & $\begin{array}{l}\text { BARI Hybrid Begun-4, BARI } \\
\text { Begun-9, Local Cultivar-1 and } \\
\text { Local Cultivar-3 }\end{array}$ & BARI Begun-9 \\
\hline 5 & $\begin{array}{l}\text { Highly } \\
\text { Susceptible } \\
\text { (HS) }\end{array}$ & $\begin{array}{l}\text { Above } \\
40 \%\end{array}$ & $\begin{array}{l}\text { BARI Hybrid Begun-2, BARI } \\
\text { Begun-10, Local Cultivar-2 and } \\
\text { Local Cultivar-4 }\end{array}$ & $\begin{array}{l}\text { BARI Hybrid Begun-2, BARI } \\
\text { Hybrid Begun-4, BARI Begun-10, } \\
\text { Local Cultivar-1 and Local Cultivar- } \\
2 \text { Local Cultivar-3 and Local } \\
\text { Cultivar-4 }\end{array}$ \\
\hline
\end{tabular}

The variationindegreeofinfestationofanypest is the combined effect of genetic architecture of crop variety and abiotic factor. The germplasm/variety cited above are not resistant/moderately resistant to this pest except the genetically modified variety BARI BT Begun- 4 . So, it can be mentioned that breeding program of thiscrop is necessary for development of resistant variety of pure line.

The mean length of fruit ranged 6.00 to $26.67 \mathrm{~cm}$ (Table 6). Only one genotype viz. Loval cultivar-2 were short fruited (fruit length $6 \mathrm{~cm}$ ); while 5 genotypes like BARI Begun-4, BARI hybrid Begun-2, BARI Hybrid Begun-4, BARI BT Begun-4 and Local Cultivar-4 hadmedium length of fruits (fruit length 7-10 cm). Other four genotype i.e. BARI Begun-9, BARI Begun-10. Local Cultivar1 and Local Cultivar-3 were having extra-long fruits (fruit length $12-22 \mathrm{~cm}$ ). There was positive non-significant correlation between the length of fruit and the degree of fruit infestation (Table 6).

The fruit diameter (FD) was between the ranges of 2.70 to $9.10 \mathrm{~cm}$ (Table 6). Two genotypes were in the range of 0 to $4 \mathrm{~cm}$ diameters viz, BARI Begun- $9(2.70 \mathrm{~cm})$ and BARI Begun-10 $(2.76 \mathrm{~cm})$. Three varieties viz. Local Cultivar-1 $(5.66 \mathrm{~cm})$, Local Cultivar-2 $(5.90 \mathrm{~cm})$ and Local Cultivar-4 $(4.73)$ was foundmedium diameter (4 to $6 \mathrm{~cm}$ ) and the other 5 genotypes viz, BARI Hybrid Begun-2 $(6.53 \mathrm{~cm})$, BARI Hybrid Begun-4 $(7.78 \mathrm{~cm})$, BARI BT Begun-4 $(9.10 \mathrm{~cm})$.

The shape index varied from 1.60 to 2.32). Six genotypes were grouped into round (shape index 1.60$21.86 \mathrm{~cm}$ ), which were Local Cultivar-3 (1.85), BARI Begun-9 (1.86), BARI Hybrid Begun-2 (1.81), Local Cultivar-1 (1.78), BARI Hybrid Begun-4 (1.60) and BARI Begun-10 (1.60). Four varieties were grouped to oval to longish (shape index 2.10 to $2.32 \mathrm{~cm}$ ) viz. BARI BTBegun-4 (2.21), Local Cultivar2 (2.32), Local Cultivar-4 (2.24) and BARI Begun-4 (2.10).

The ratio of the length of peripheral seed ring to total length of the fruit (RLPS) indicating the degree of mechanical seed barrier to the entry of borer varied from $(0.132$ to 0.641$)$ as given in Table 6 . The less RLPS (0.132 to 0.189) was observed in five genotypes, which were BARI Hybrid Begun-4 (0.132), BARI Begun-4 (0.137), BARI hybrid Begun-2(0.140), BARI BT Begun-4 (0.163) and Local Cultiva-2 (0.189). The medium RLPS $(0.203$ to 0.348$)$ was found in four varieties, which were Local Cultivar-1 (0.203), Local Cultivar-3 (0.249), Local Cultivar-4 (0.300) and Bari Begun-10 (0.348. Thehigh RLPS (above 0.500) was recorded from only one variety named BARI Begun-9 (0.641). The ratioof length of seedless area to the total length of fruit indicating the pulpiness of fruit ranged 0.060 to 0.198 .

Table 6. Characters of brinjal fruit in relation to shoot and fruit borer incidence

\begin{tabular}{|c|c|c|c|c|c|c|c|c|c|c|}
\hline \multirow{2}{*}{$\begin{array}{l}\text { S. } \\
\text { N. }\end{array}$} & \multirow[t]{2}{*}{ Germplasm } & \multirow{2}{*}{$\begin{array}{l}\text { Fruit } \\
\text { length } \\
(\mathrm{cm})\end{array}$} & \multirow{2}{*}{$\begin{array}{c}\text { Fruit } \\
\text { diameter } \\
(\mathbf{c m})\end{array}$} & \multirow{2}{*}{$\begin{array}{c}\text { Shape } \\
\text { index } \\
(\mathbf{l} / \mathbf{d})\end{array}$} & \multirow{2}{*}{$\begin{array}{c}\text { Volume } \\
\text { index (lxd) }\end{array}$} & \multirow[b]{2}{*}{ RLPS } & \multirow[b]{2}{*}{ RLSA } & \multicolumn{2}{|c|}{$\begin{array}{l}\text { Thickness of } \\
\end{array}$} & \multirow{2}{*}{$\begin{array}{c}\text { Fruit } \\
\text { infestation } \\
(\%)\end{array}$} \\
\hline & & & & & & & & Pericarp & Mesocarp & \\
\hline 1 & $\begin{array}{l}\text { BARI Hybrid } \\
\text { Begun-2 }\end{array}$ & $9.54 \mathrm{~b}$ & $6.53 \mathrm{~cd}$ & $1.81 \mathrm{bc}$ & $605.00 \mathrm{a}$ & $0.140 \mathrm{~d}$ & $0.117 \mathrm{bc}$ & $0.47 \mathrm{ab}$ & $8.98 \mathrm{abc}$ & $80.60 \mathrm{a}$ \\
\hline 2 & BARI Hybrid & $7.78 b$ & $6.07 \mathrm{de}$ & $1.60 \mathrm{c}$ & $614.83 \mathrm{a}$ & $0.132 \mathrm{~d}$ & $0.156 \mathrm{ab}$ & $0.55 \mathrm{ab}$ & $8.86 \mathrm{abc}$ & $75.60 \mathrm{a}$ \\
\hline
\end{tabular}




\begin{tabular}{clccccccccc} 
& Begun-4 & & & & & & & & \\
3 & BARI BTBegun-4 & $10.61 \mathrm{~b}$ & $9.10 \mathrm{a}$ & $2.21 \mathrm{ab}$ & $373.00 \mathrm{bc}$ & $0.163 \mathrm{~cd}$ & $0.195 \mathrm{a}$ & $0.61 \mathrm{a}$ & $10.78 \mathrm{a}$ & $4.20 \mathrm{c}$ \\
4 & BARI Begun-9 & $19.78 \mathrm{ab}$ & $2.70 \mathrm{~g}$ & $1.86 \mathrm{abc}$ & $392.67 \mathrm{abc}$ & $0.641 \mathrm{a}$ & $0.061 \mathrm{c}$ & $0.23 \mathrm{c}$ & $10.01 \mathrm{ab}$ & $34.20 \mathrm{bc}$ \\
5 & BARI Begun-10 & $21.39 \mathrm{ab}$ & $2.76 \mathrm{~g}$ & $1.60 \mathrm{c}$ & $592.00 \mathrm{ab}$ & $0.347 \mathrm{~b}$ & $0.116 \mathrm{bc}$ & $0.43 \mathrm{~b}$ & $10.82 \mathrm{a}$ & $53.90 \mathrm{abc}$ \\
6 & Local Cultivar-1 & $13.44 \mathrm{ab}$ & $5.66 \mathrm{e}$ & $1.78 \mathrm{bc}$ & $507.25 \mathrm{ab}$ & $0.203 \mathrm{bcd}$ & $0.154 \mathrm{ab}$ & $0.48 \mathrm{ab}$ & $7.39 \mathrm{abcd}$ & $71.93 \mathrm{ab}$ \\
7 & Local Cultivar-2 & $6.00 \mathrm{~b}$ & $5.90 \mathrm{de}$ & $2.32 \mathrm{a}$ & $400.83 \mathrm{abc}$ & $0.189 \mathrm{~cd}$ & $0.156 \mathrm{ab}$ & $0.52 \mathrm{ab}$ & $2.78 \mathrm{bcd}$ & $55.23 \mathrm{abc}$ \\
8 & Local Cultivar-3 & $26.67 \mathrm{a}$ & $7.29 \mathrm{bc}$ & $1.85 \mathrm{abc}$ & $264.00 \mathrm{c}$ & $0.249 \mathrm{bcd}$ & $0.198 \mathrm{a}$ & $0.51 \mathrm{ab}$ & $1.87 \mathrm{~cd}$ & $72.77 \mathrm{ab}$ \\
9 & Local Cultivar-4 & $9.70 \mathrm{~b}$ & $4.73 \mathrm{f}$ & $2.24 \mathrm{ab}$ & $268.33 \mathrm{c}$ & $0.300 \mathrm{bc}$ & $0.146 \mathrm{ab}$ & $0.43 \mathrm{~b}$ & $2.43 \mathrm{~cd}$ & $57.50 \mathrm{abc}$ \\
10 & BARI Begun-4 & $8.06 \mathrm{~b}$ & $7.81 \mathrm{~b}$ & $2.10 \mathrm{ab}$ & $367.58 \mathrm{bc}$ & $0.137 \mathrm{~d}$ & $0.188 \mathrm{a}$ & $0.56 \mathrm{ab}$ & $1.83 \mathrm{~cd}$ & $45.47 \mathrm{abc}$ \\
\hline & LSD Value & 13.98 & 0.87 & 0.46 & 224.56 & 0.155 & 0.066 & 0.17 & 7.37 & 35.98 \\
\hline
\end{tabular}

The pericarp thickness of fruit varied from $(2.33$ to $6.11 \mathrm{~cm})$ (Table 4.5$)$. Only one genotype was found with medium pericarp $(0.15$ to $0.35 \mathrm{~cm})$, which was BARI Begun- $9(0.23 \mathrm{~cm})$. The other 9 varieties had broader pericarp $(0.47-0.56)$.

The thickness of mesocarp varied 1.83 to $10.82 \mathrm{~cm}$ (Table 6). The narrow mesocarp (1 to $2.78 \mathrm{~cm}$ ) was found in four genotypes i.e. Local Cultivar-2 $(2.78 \mathrm{~cm})$, Local Cultivar-3 $(1.87 \mathrm{~cm})$, Local Cultivar-4 $(2.43 \mathrm{~cm})$, BARI Begun-4 $(1.83 \mathrm{~cm})$. The medium mesocarp was measured from three varieties ranged ( 7.0 to $8.98 \mathrm{~cm})$ viz. BARI Hybrid Begun-2 $(8.98 \mathrm{~cm})$, BARI Hybrid Begun-4 $(8.86 \mathrm{~cm})$ and Local Cultivar-1 $(7.39 \mathrm{~cm})$. The broader mesocarp was calculated from three varieties ranged above $10.0 \mathrm{~cm}$, which were BARI BT Begun-4 $(10.78 \mathrm{~cm})$, BARI Begun-9 $(10.01 \mathrm{~cm})$ and BARI Begun-10 (10.82 $\mathrm{cm})$.

Correlation matrix between fruit infestation and fruit length, fruit diameter, shape index, volume index, RLPS (Ratio of Length of Pericarpal Seed ring), RLSA (Ratio of Length of Seedless Area) and thickness of pericarp and mesocarp was develop to asses of effect of fruit character on the infestation of fruit borer (Table 7). It was observed that shape index, RLSA and pericarp has significant negative association with fruity infestation $(r=-0.334,-0.365$ and -0.384 , respectively), whereas thickness of mesocarp was positively significantly correlated $(r=0.445)$. Other factors like fruit length, fruit diameter, volume index and RLPS had non-significant impact in fruit infestation. However, the shape index is the ratio of fruit length and fruit diameter; fruit length had negative association with fruit infestation, while fruit diameter was associated positively. This indicated that enhancement in fruit length reduces the fruit infestationwhereas the fruit diameter increases the infestation (Table 7).

Table 7. Relationship of fruit infestation with fruit characters in brinjal

\begin{tabular}{lcccccccc}
\hline \multicolumn{1}{c}{ Character } & $\begin{array}{c}\text { Fruit } \\
\text { Diameter }\end{array}$ & $\begin{array}{c}\text { Shape } \\
\text { index }\end{array}$ & $\begin{array}{c}\text { Volume } \\
\text { index }\end{array}$ & RLPS & RLSA & $\begin{array}{c}\text { Pericarp } \\
\text { thickness }\end{array}$ & $\begin{array}{c}\text { Mesocarp } \\
\text { thickness }\end{array}$ & $\begin{array}{c}\text { Fruit } \\
\text { infestation }\end{array}$ \\
\hline Fruit length & $0.731^{* *}$ & -0.334 & $0.850^{* *}$ & -0.347 & -0.281 & 0.128 & $0.518^{* *}$ & -0.091 \\
Fruit diameter & & $-0.861^{* *}$ & $0.978^{* *}$ & -0.124 & $-0.400^{*}$ & -0.114 & $0.858^{* *}$ & 0.322 \\
Shape index & & & $-0.747^{* *}$ & -0.041 & $0.356^{*}$ & 0.237 & $-0.810^{* *}$ & -0.334 \\
Volume index & & & & -0.207 & $-0.383^{*}$ & -0.045 & $0.804^{* *}$ & 0.260 \\
RLPS & & & & $0.667^{* *}$ & $-0.807^{* *}$ & 0.318 & 0.350 \\
RLSA & & & & & $0.899^{* *}$ & $-0.785^{* *}$ & $-0.365^{*}$ \\
Pericarp thickness & & & & & & & $-0.609^{* *}$ & $-0.384^{*}$ \\
Mesocarp thickness & & & & & & & $0.455^{*}$ \\
\hline
\end{tabular}

It can be summarized that long fruit with more thickness of mesocarp were having less infestation of fruit borer in brinjal crop. These investigations was corroborates with the findings ofMote, 1976)who reported that there were negative correlation of thickness of mesocarp and fruit infestation in brinjal.

\section{Conclusion}


It can be concluded from the present experiment that out of the 10 Local Cultivars and varieties of brinjal screened against shoot and fruit borer, none was found completely free from infestation of the shoot and fruit borer. However, the genetically modified brinjal variety BARI BT Bgun-4 was recorded lowest percent of shoot and fruit infestation(rating scale- 1) with highly resistant capacity and higher yield than remaining cultivars.

\section{Acknowledgement}

The author are hereby gratefully acknowledge the Khulna University Research Cell for providing fund to conduct the study properly.

\section{References}

Amin, M. R., Miah, M. S., Rahman, H., Nancy, N. P. and Bhuiyan, M. K. A. 2018. Functional and group abundance of insects on eggplant. Ban. J.Agri. Res., 43(4), 647-653.

Ashoke K. and Abhishek S. 2002. Varietal preference of fruit and shoot borer, Leucinodesorbonalis Guen. onbrinjal. Insect Environ. 8(1):44.

BBS. 2020. Yearbook of Agricultural Statistics-2020 (Vol. 31st series). Bangladesh: Bangladesh Bureau of Statistics (BBS). Retrieved from http://bbs.portal.gov.bd/sites/default/files/files/bbs.portal.gov.bd/page/1b1eb817_9325_4354_a756 _3d18412203e2/2020-10-06-09-58-453f7e0a42348e05f0999979870ec 07b. pdf

Braga, P. C., Lo Scalzo, R., dal Sasso, M., Lattuada, N., Greco, V. and Fibiani, M. (2016). Characterization and antioxidant activity of semi-purified extracts and pure delphinine-glycosides from eggplant peel (Solanummelongena L.) and allied species. J. Funct. Foods 20, 411-421. doi: 10.1016/j.jff.2015.10.032

Cao, G., Sofic, E. and Prior, R. L. 1996. Antioxidant capacity of tea and common vegetables. J. Agric. Food Chem. 44, 3426-3431. doi: 10.1021/jf9602535

Chakraborti, S. and Sarkar, P. 2011. Management of Leucindesorbonalis Guenee on Eggplants during the rainy season in India. Plant Protect. Res. J. 51 (4), 325-328.

Chaudhary D.R. and Sharma S.D. 2000. Screening of some brinjal cultivars against bacterial wilt and fruit borer. Agric. Sci. Digest.,20(2):129-130.

Daunay, M. C. and Hazra, P. 2012. "Eggplant," in Handbook of Vegetables, eds K. V. Peter and P. Hazra (Houston, TX: Studium Press), 257-322.

Docimo, T., Francese, G., Ruggiero, A., Batelli, G., De Palma, M. and Bassolino, L. 2016. Phenylpropanoids accumulation in eggplant fruit: characterization of biosynthetic genes and regulation by a MYB transcription factor. Front. Plant Sci. 6:1233. doi: 10.3389/fpls.2015.01233.

FAO. 2019. Compare Data. Retrieved January 30, 2021, from FAOSTAT: http://www.fao.org/faostat/en/\#compare

Gangopadhyay C, Maity T.K. and Mandal S.K. 1996. Screening of brinjal germplasms against fruit and shoot borer, Leucinodesorbonalis Guen. Environ. and Ecol., 14:834-836.

Gomez, K. A., \& Gomez, A. A. 1984. Statistical procedures for agricultural research. John Wiley \& Sons.

JatK.L. 2003. Biophisical and biochemical factor of resistance in brinjal against Leucinodesorbanalis Guen. Indian Journal of Entomology,65(2):252-259.

Jayaraj, J. and Manisegaran, S., 2010. Management of fruit and shoot borer in brinjal. The Hindu Sci-Tech. Agri. College and Res. Inst. Madurai. 
Kalloo, G. (993) Eggplant: Solanummelongena L. Genetic improvement of vegetable crops, 587-604.

Kar, D., Kuanar, A., Ray, A., Gaur, M., Pattanaik, B. and Mishra, B. 2020. Genetic Diversity of Brinjal Fruit and Shoot Borer (BSFB) Population of Odisha, India. Iranian Journal of Science and Technology, Transactions A: Science, 1-10.

Karim A.N.M.R. 2004.IPM for vegetable crops: issues and technology developments in Bangladesh. A keynote paper presented at the sixth biennial conference of Bangladesh Entomological Society held at BARI, Joydebpur, Gazipur, Bangladesh, October 7, 2004; 2004.

Krishna T.M, Lal O.P., Srivastava Y.N. 2001. Extent of losses caused by shoot and fruit borer, Leucinodesorbonalis Guen., to promising varieties of brinjal, Solanummelongena L. J Entomol. Res., 25(3):205-212.

Kumar A. and Shukla A. 2002. Varietal preference of fruit and shoot borer, Leucinodeorbonalis Guen. onbrinjal. Insect Environment. 2002;8(1):44.

Mennella, G., Lo Scalzo, R., Fibiani, M., D'Alessandro, A., Francese, G., Toppino, L., et al. 2012. Chemical and bioactive quality traits during fruit ripening in eggplant (S. melongena $L$.) and allied species. J. Agric. Food Chem. 60, 11821-11831. doi: 10.1021/jf3037424

Naeem, M. Y. andUgur, S. 2019. Nutritional Content and Health Benefits of Eggplant. Turkish Journal of Agriculture-Food Science and Technology, 7(sp3), 31-36.

Niño-Medina, G., Urías-Orona, V., Muy-Rangel, M. D., \& Heredia, J. B. (2017). Structure and content of phenolics in eggplant (Solanummelongena)-a review. South African Journal of Botany, 111, 161169.

Plazas, M., Andújar, I., Vilanova, S., Gramazio, P., Herraiz, F. J. 2014a. Conventional and phenomics characterization provides insight into the diversity and relationships of hypervariable scarlet (Solanumaethiopicum L.) and gboma (S. macrocarpon L.) eggplant complexes. Front. Plant Sci. 5:318. doi: 10.3389/fpls.2014.00318

Plazas, M., Andújar, I., Vilanova, S., Hurtado, M., Gramazio, P., Herraiz, F. J. (2013. Breeding for chlorogenic acid content in eggplant: interest and prospects. Not. Bot. Horti. Agrobot. 41, 26-35. doi: $10.15835 /$ nbha4119036

Raigón, M. D., Prohens, J., Muñoz-Falcón, J. E., and Nuez, F. 2008. Comparison of eggplant landraces and commercial varieties for fruit content of phenolics, minerals, dry matter and protein. J. Food Comp. Anal. 21, 370-376. doi: 10.1016/j.jfca.2008.03.006.

Rashid, M.M. 1999.Begun Paribarer Shabji. pp. 137 -154. In: Shabji Biggan(in Bangla). 1sted. Bangla Academy, Dhaka, Bangladesh. 515 p.

Sardana H.P., Arora S, Singh D.K., Kadu L.N. 2004. Development and validation of adaptable Integrated Pest Management in eggplant, Solanummelongena $L$. in a farmers participatory approach. Indian Journal of Plant Protection. 2004; 32:123-128.

Schippers, R. R. 2000. African Indigenous Vegetables: An Overview of the Cultivated Species. Natural Resources Institute/ACP-EU Technical Centre for Agricultural and Rural Cooperation, Chatham, UK.

Stommel, J. R., Whitaker, B. D., Haynes, K. G., and Prohens, J. 2015. Genotype $\times$ environment interactions in eggplant for fruit phenolic acid content. Euphytica 205, 823-836. doi: 10.1007/s10681-015$1415-2$

Taylo, L.D., Sison M.L.J. and Hautea D.M. 2016. Use of artificial infestation for field bioefficacy assessment of Bt eggplant against the eggplant fruit and shoot borer, Leucinodesorbonalis Guenee (Lepidoptera: Crambidae). Philipp. Agric. Sci. 99:119-126.

Yadav D.S. andSharma MM. 2005. Evaluation of brinjal varities foe their resistance against fruit and shoot 
borer, Leucinodesorbonalis Guen. Indian Journal of Entomology, (2):129-132.

Yadav LN, Sharma J.K., Yadav S.K. 2003. Varietal Screening of brinjal against fruit and shoot borer, Leucinodesorbonalis Guen. Annals of Agro Bio Research, 8(1):77-80. 